\title{
Figure S2
}

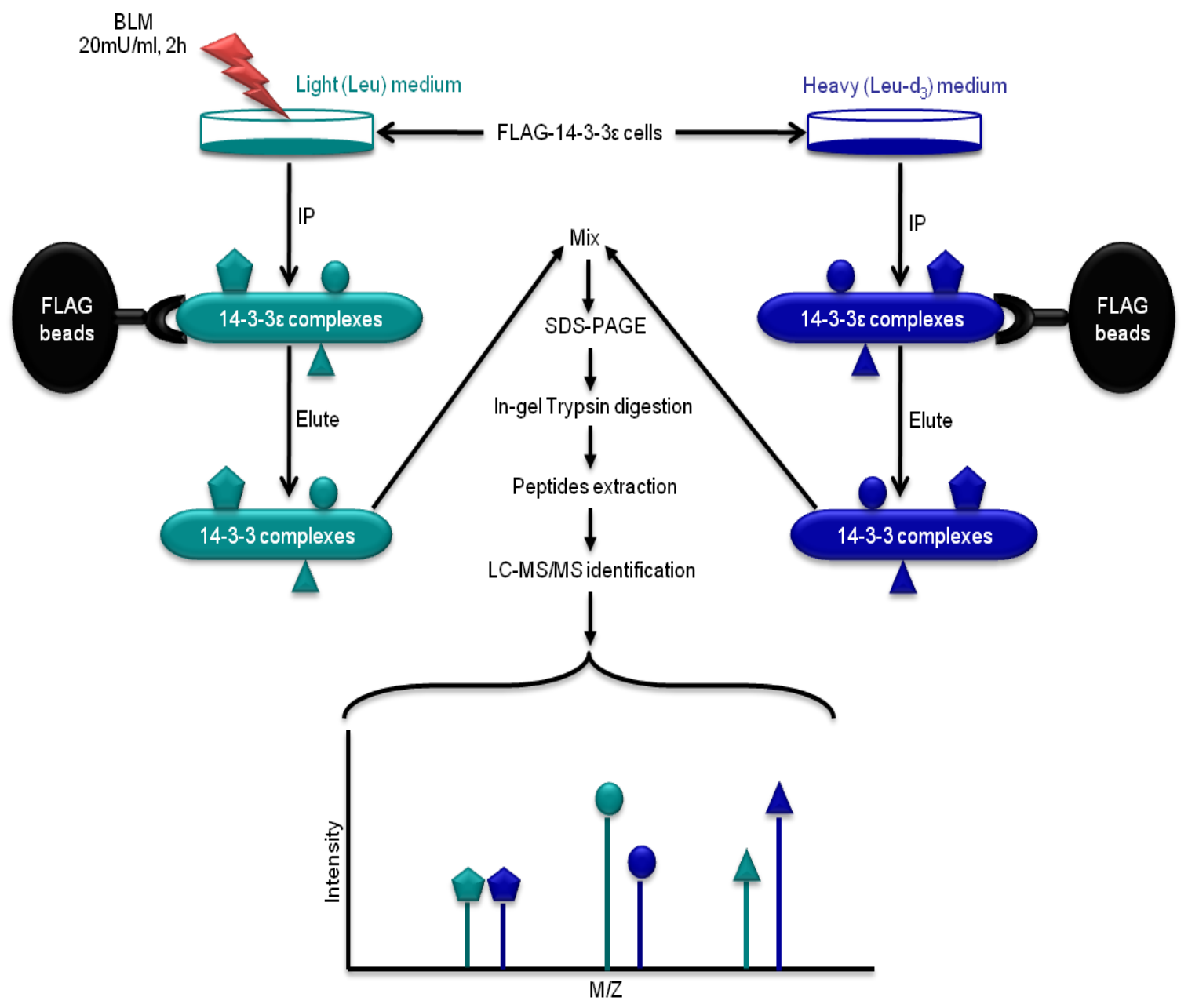

Figure S2. Schematic design of dual-tagging quantitative proteomic approach. HCC cells stably expressing FLAG-14-3-3e maintained in "light" medium (Leu) were treated with $20 \mathrm{mU} / \mathrm{ml} \mathrm{BLM}$ for $2 \mathrm{~h}$. In parallel, cells maintained in "heavy" medium $\left(\right.$ Leu- $\left.\mathrm{d}_{3}\right)$ were left untreated. The FLAG-14-3-3e complex were immunoprecipitated (IP) from the whole cell lysate derived from each cell pool using anti-FLAG beads and eluted by $1 \times$ FLAG peptide, respectively. IP products were then mixed at 1:1 based on the total protein mass followed by SDS-PAGE separation, in-gel trypsin digestion, and LC-MS/MS analysis. 